AGRARIS: Journal of Agribusiness and Rural Development Research

Vol. 3 No. 2 J uli 2017

\section{Strategi Pengembangan Sub Terminal Agribisnis (STA) Salak Pondoh di Kabupaten Sleman}

https://doi.org/10.18196/agr.3249

\begin{abstract}
The purpose of this study is to know the existing conditions and to identify need of assesements for Sub Terminal Agribisnis (STA) Tempel in Sleman Regency. Data were collected through direct observation, focus group discussion (FGD) and study documents from related institutions. The existing conditions of STA Tempel was analyzed qualitatively and quantitatively, while need of assessment for STA Tempel was analyzed by SWOT. The results showed that STA Tempel has not been able to perform the function properly. To improve the performance, STA Tempel must increase function of marketing of agricultural commodities; integrate with other trading activities; develop promotion; optimize of human resource functions; build modern facilities and infrastructures; and optimize the role of STA as a training and education center.
\end{abstract}

Keywords: existing condition, need of assesments, STA Tempel, strategy.

\section{INTISARI}

Studi ini bertujuan untuk mengetahui kondisi existing dan need of assesements Sub Terminal Agribisnis (STA) Tempel di Kabupaten Sleman. Pengumpulan data diperoleh melalui observasi langsung dan focus group discussion (FGD) serta studi dokumen dari instansi terkait. Kondisi existing STA Tempel dianalisis secara kualitatif dan kuantitatif, sedangkan need of assesements STA Tempel dianalisis dengan SWOT. Hasil penelitian menunjukkan bahwa STA Tempel belum mampu melaksanakan fungsinya secara optimal dan manfaatnya belum dirasakan petani. Peningkatan kinerja STA Tempel dilakukan dengan peningkatan fungsi pemasaran komoditas pertanian; integrasi dengan kegiatan perdagangan lain; pengembangan promosi produk; optimalisasi fungsi sumber daya manusia (SDM) pengelola dan anggota; membangun sarana dan prasarana modern; dan optimalisasi peran STA sebagai pusat pelatihan dan pendidikan.

Kata kunci: kondisi existing, need of assesments, STA Tempel, strategi.

\section{PENDAHULUAN}

M enurut Badan A gribisnis D epartemen Pertanian, selama ini pemasaran bidang pertanian mempunyai mata rantai yang panjang, mulai dari petani, pedagang pengumpul, pedagang besar sampai konsumen, sehingga keuntungan yang diperoleh petani relatif kecil. Di sisi lain, konsumen harus membayar lebih mahal dari harga yang selayaknya karena setiap lembaga mengambil keuntungan dalam proses pemasaran. Fluktuasi harga produk pertanian di tingkat petani lebih tinggi daripada harga di tingkat konsumen (Susanawati, Jamhari, M asyhuri \& D arwanto, 2015). Salah satu upaya untuk meningkatkan efisiensi pemasaran dan nilai tambah petani adalah dengan mengembangkan infrastruktur pemasaran seperti Sub Terminal Agribisnis (STA).

Berdasarkan konsep Badan A gribisnis D epartemen Pertanian, STA sebagai infrastruktur pemasaran diharapkan bermanfaat untuk lima aspek. Pertama, STA memperlancar kegiatan dan meningkatkan efisiensi pemasaran komoditas agribisnis karena mencakup sebagai pusat transaksi hasil-hasil agribisnis; 
memperbaiki struktur pasar, cara dan jaringan pemasaran; sebagai pusat informasi pertanian serta sebagai sarana promosi produk pertanian. Kedua, STA mempermudah pembinaan mutu hasil-hasil agribisnis yang meliputi; penyediaan tempat sortasi dan pengemasan; penyediaan air bersih, es, gudang, cool room dan cold storage; melatih para petani dan pedagang dalam penanganan dan pengemasan hasil pertanian. Ketiga, STA menjadi wadah bagi pelaku agribisnis untuk merancang bangun pengembangan agribisnis, menyinkronkan permintaan pasar dengan manajemen lahan, pola tanam, kebutuhan sarana produksi dan permodalan serta peningkatan SDM pemasaran. Keempat, STA meningkatkan peningkatan pendapatan daerah melalui jasa pelayanan pemasaran. Terakhir, STA mendorong pengembangan agribisnis dan wilayah.

Studi sebelumnya menunjukkan peranan penting STA di beberapa wilayah. Di Kabupaten Tuban, STA berperan penting dalam upaya pengembangan agroindustri perikanan laut secara terpadu di Kecamatan Tambakboyo (Fatih, 2010). STA di wilayah tersebut terdiri dari mitra pasar, koperasi dan industri besar sebagai tempat pemasaran bagi produk yang dihasilkan oleh kelompok usaha agroindusti tersebut. Di Kabupaten Sikka, STA berhasil meningkatkan kinerja pemasaran meningkatkan pendapatan masyarakat (Noni, D armawan \& Suarthana, 2013). Keberhasilan pembangunan STA didukung faktor man, money, method, machines, dan market. Di K abupaten M agelang, pedagang pengguna STA sangat puas terhadap kinerja pengelola STA, khususnya pada aspek kenyamanan tempat, tingkat pelayanan dan harga sewa lokasi (Suranto, 2010).

N amun, beberapa studi menunjukkan tidak semua STA memiliki kinerja memuaskan. Pemasaran sayuran wortel di STA K abupaten Karanganyar menunjukkan nilai elastisitas transmisi harga kurang dari 1, artinya laju perubahan harga di tingkat petani lebih kecil dari laju perubahan harga di tingkat konsumen dan pasar berbentuk pasar persaingan tidak sempurna (Cahyono, Kusnandar, \& Sri, 2013). H asil analisis marjin pemasaran, farmer's share, efisiensi operasional, dan efisiensi harga menunjukkan bahwa secara umum pemasaran di STA Karanganyar belum efisien.

Selain faktor manajemen pengelola, ada beberapa faktor yang menyebabkan STA di Indonesia kurang berkembang. Faktorfaktor tersebut antara lain: (i) petani maupun para pelaku kegiatan tata niaga lainnya masih melakukan pemasaran langsung kepada pedagang pengumpul, bahkan langsung ke pedagang besar yang datang ke lokasi produksi; (ii) ketergantungan petani dalam sistem permodalan usahatani terhadap pinjaman dari pemilik modal yang sekaligus sebagai pedagang, sehingga untuk mengembalikan modal maka penjualan hasil produksi banyak dilakukan kepada pedagang pemberi modal; (iii) keberadaan dan fungsi STA belum banyak diketahui oleh sebagian petani karena lokasi STA yang kurang strategis (Pujihanto, 2010). Faktor lainnya yaitu perubahan iklim dan cuaca yangtidak menentu dan hargajual produk yangfluktuatif (Bank Indonesia, 2015).

Dengan melihat berbagai keadaan STA di Indonesia, maka menjadi suatu hal yang menarik untuk mengkaji STA Tempel. Pada awal pendirian, STA ini diharapkan dapat membantu memperpendek saluran pemasaran produk pertanian di Sleman, terutama salak pondoh. Namun, STA Tempel belum beroperasional secara optimal, sehingga dampak keberadaan fasilitas ini belum dirasakan berbagai lembaga pemasaran pertanian, terutama petani. Dengan melihat kondisi tersebut, diperlukan studi untuk mengetahui kondisi existing dan mengidentifikasi kebutuhan (need assesements) STA Tempel di K abupaten Sleman.

\section{METODE PENELITIAN}

Penelitian ini dilaksanakan pada bulan Juni-September tahun 2015. Pengumpulan data melalui observasi langsung dan FG D dengan melibatkan Bappeda, pengelola STA, D inas Teknis dan kelompok tani di Kabupaten Sleman. Selain itu juga dilakukan studi dokumen dari instansi terkait.

Kondisi existing STA Tempel dianalisis secara kualitatif berdasarkan wawancara dengan instansi terkait, pengelola STA, kelompok tani, asosiasi dan pengusaha. A nalisis kuantitatif juga dilakukan berdasarkan data yang dikumpulkan dari instansi terkait, terutama kajian/studi terdahulu yang berkaitan dengan kajian ini meliputi Feasible Study STA Tempel, Peraturan Bupati/Keputusan Kepala Dinas tentang STA dan Komoditas U nggulan, Rencana Pengembangan Komoditas Potensial di Sleman Timur, Pengembangan Kawasan Sentra Produksi Pertanian Lereng M erapi Bagian Selatan, serta Pengembangan Komoditas Pertanian U nggulan Kabupaten Sleman. Identifikasi kebutuhan (need assesements) dan rekomendasi dalam rangka pengembangan STA Tempel dianalisis dengan SW OT (Tabel 1). M elalui analisis SW OT, diperoleh strategi yang tepat dalam pengembangan STA Tempel.

\section{HASIL DAN PEMBAHASAN} PROFIL STA TEM PEL

STA Tempel di Kabupaten Sleman didirikan tahun 2006 dengan bentuk kelembagaan berupa U nit Pelaksana Teknis (UPT) dari Dinas Pertanian Perikanan dan Kehutanan. 
TABH 1 MAIRKSSNOT

\begin{tabular}{|c|c|c|}
\hline Etard Fatas & Shagts(9) & Utrexesy \\
\hline Qpotuites(9) & 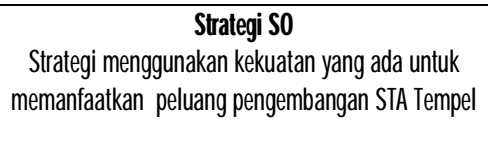 & 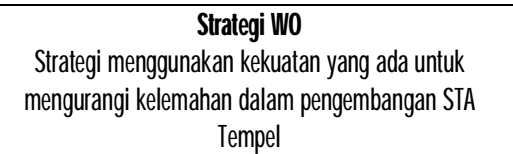 \\
\hline Thess(1) & 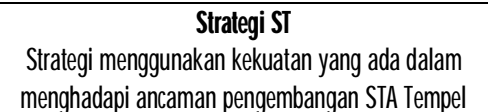 & 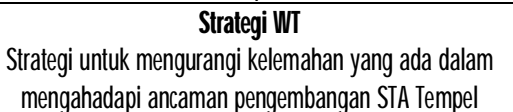 \\
\hline
\end{tabular}

Berdasarkan dokumen awal pendirian, STA Tempel pada awalnya diarahkan sebagai Terminal A gribisnis(TA). M enurut dokumen feasibility study (FS) STA Tempel dalam kategori layak baik secara finansial, sosio kultural dan kelembagaan. Dilihat secara fin ansial, STA ini menguntungkan ditunjukkan oleh $B / C$ ratio 1,29 dengan periodekembali modal sekitar 8 tahun 3 bulan dari tahun awal pendirian STA. STA Tempel merupakan UPT yang mempunyai tugas pokok dan fungsi (Tupoksi) bidang promosi dan pemasaran, antara lain:

a. sebagai tempat transaksi dan jual beli dengan menyediakan tempat bagi produsen dan konsumen untuk transaksi hasil komoditas pertanian secara berkelanjutan, sebagai jalur distribusi produksi pertanian, meningkatkan pendapatan petani produsen, memberikan kemudahan, kenyamanan dan perlindungan bagi konsumen serta sebagai pusat kegiatan penanganan pascapanen (sortasi, grading, pengepakan dan cold storage),

b. sebagai pusat informasi bagi produsen dan konsumen mengenai volume, macam, waktu ketersediaan, komoditas yang ditawarkan, serta sebagai forum komunikasi antara kelompok petani dan produsen,

c. sebagai tempat pendidikan yang berfungsi untuk pelatihan bagi masyarakat dalam meningkatkan hasil pertanian, pengelolaan, pemasaran dan manajemen, serta tempat magang bagi masyarakat untuk mengetahui proses kegiatan pemasaran,

d. sebagai tempat pariwisata yang berfungsi untuk rest area dan pameran hasil pertanian.

STA Tempel dijalankan dengan pendanaan dari A PBD, sedangkan target pendapatan yang ditetapkan Pemkab Sleman untuk STA Tempel sebesar Rp 25 juta per tahun. U ntuk mencapai target PAD, maka kegiatan utama yang dilakukan STA Tempel adalah budidaya buah naga. Kegiatan ini sebenarnya tidak sesuai dengan fungsi STA sebagai lembaga pemasaran, namun pada kenyataannya budidaya buah naga menjadi sumber pendapatan utama yang dihasilkan oleh STA.

\section{KONDISI EXISTING DAN NEED ASSESM ENTS STA TEMPEL}

Secara umum, fungsi yang seharusnya dilaksanakan STA Tempel belum berjalan dengan baik. D aya tarik STA untuk petani masih rendah, hal tersebut terlihat dari rendahnya tingkat partisipasi petani untuk melakukan aktivitas pemasaran dan pencarian informasi harga melalui STA. H al ini terjadi karena petani sudah memiliki alternatif pemasaran dan sumber informasi pasar yang mudah dicapai dan lebih aktual. Keadaan tersebut hampir sama dengan keadaan di STA Mantung. Petani cenderung mengutamakan sistem pemasaran kelembagaan tradisional dibandingkan STA Mantung dikarenakan ketersediaan informasi harga dan kemudahan prosedur transaksi yang ditawarkan pada kelembagaan tradisional, dimana hal ini diduga karena belum berfungsinya layanan pada STA M antung, seperti layanan lelang dan informasi harga (Anindita, 2008).

TARI 2 BSPORSAAKPONOHSATIEM田

\begin{tabular}{|c|c|c|}
\hline $\mathbf{N b}$ & Atan & Katites(kirta) \\
\hline \multicolumn{3}{|c|}{ TijuenSingpara } \\
\hline 1 & Janai 2015 & 2340 \\
\hline 2 & Feburi 2015 & 1850 \\
\hline 3 & Nate 2015 & 3.070 \\
\hline 4 & Apil 2015 & 2060 \\
\hline 5 & $\mathrm{Mi} 2015$ & 1980 \\
\hline \multicolumn{3}{|c|}{ Tujuenara } \\
\hline 1 & Janari 2015 & 6.150 \\
\hline
\end{tabular}

Sebagai tempat transaksi, pada kenyataannya saat ini STA tidak melakukan transaksi jual beli produk pertanian dari 
petani. STA lebih fokus pada kegiatan penjualan buah naga hasil kebun di STA. Padahal, potensi untuk membantu transaksi penjualan komoditas lain juga sangat besar. Salah satunya adalah salak pondoh yang sudah dapat diekspor ke Singapura dan Cina dengan kuantitas yang cukup besar (Tabel 2).

STA berperan dalam memaparkan jenis, kuantitas dan harga komoditas yang tersedia di Sleman. Namun, pada kenyataannya fungsi ini juga tidak berjalan. Sebagai tempat pendidikan, kuantitas pelatihan yang diadakan STA tiap tahunnya masih sedikit, padahal pelatihan sangat diperlukan oleh petani, baik tentang budidaya maupun pascapanen serta pemasaran produk.

\section{SUMBER DAYA MANUSIA}

Struktur organisasi ideal STA pada awal pendirian sesuai feasibility study seperti pada bagan dalam Gambar 1 . Pada kenyataannya, struktur organisasi STA belum terbentuk secara ideal. Saat ini STA hanya terdiri dari kepala dan 3 orang staf. Jumlah tersebut masih kuranguntuk menjalankan tugas STA. Secara kualitas, diperlukan pegawai yang ahli dalam bisnis untuk menjalankan fungsi STA sebagai lembaga transaksi dan jual beli. STA juga membutuhkan ahli dalam bidang teknologi informasi untuk menjalankan fungsi informasi baik secara offline (langsung tatap muka dengan produsen dan konsumen) maupun secara online (melalui media informasi website, media sosial, dan lainnya).

\section{SARANA PRASARANA}

Pada awal pendirian, STA memiliki beberapa fasilitas penunjang yang wajib dimiliki untuk menjalankan fungsi transaksi, informasi, pendidikan dan pariwisata. Berdasarkan

\section{TABI3 KEADANSARANAPRASABANSTATAHN2015}

\begin{tabular}{|c|c|c|}
\hline $\mathbf{N}$ & Feilla & Kadtanstiri \\
\hline 1 & $\begin{array}{l}\text { Gedtry perampengen dan } \\
\text { sotas 3bah@ 8x16na }\end{array}$ & $\begin{array}{l}\text { Henyal, tickmementi } \\
\text { serd }\end{array}$ \\
\hline 2 & Pengenжsan@ 8x20n² & Tickkadk \\
\hline$\Xi$ & ddStoage@ 4x8n² & Tickkadk \\
\hline 4 & Lospddangan4bah $50 n^{2}$ & AlE \\
\hline 5 & Cedrgsabagra & Tickkadb \\
\hline 6 & Penginean(10kanæ) & Tickkadb \\
\hline 7 & Mshda8x8nå & Tickkadb \\
\hline$\varepsilon$ & KantoPengadde & $A \notin E$ \\
\hline$\underline{\mathrm{C}}$ & RustInfanæ: Peckagrger & Tickkak \\
\hline $1 C$ & PustIIfamæ Snate & Tidkaak \\
\hline 11 & 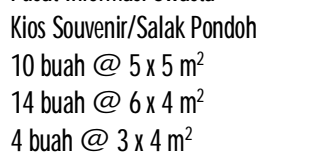 & Tickkada \\
\hline 12 & Srkulä & Tickkada \\
\hline 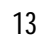 & RunthNakar & Tickkadk \\
\hline 14 & RangPanerar & Tickkak \\
\hline 15 & MK2ban@32n & AdE \\
\hline
\end{tabular}

kriteria kepemilikan fasilitasideal, jelas terlihat bahwa banyak fasilitas penunjang yang tidak dimiliki oleh STA untuk menjalankan fungsi idealnya (Tabel 3). $\mathrm{H}$ al ini terjadi karena sumber dana untuk pengembangan fasilitas yang dimiliki STA hanya diperoleh dari APBD dimana jumlah dana yang didapatkan belum cukup untuk mewujudkan fasilitassesuai dengan feasibility study yang telah dibuat. Keterbatasan pendanaan STA menjadi salah satu faktor penghambat dalam menjalankan fungsi sesuai dengan rencana pembangunan. Pemerintah Kabupaten Sleman sebenarnya dapat memberikan kesempatan kepada pihak swasta untuk berkontribusi bagi kemajuan STA melalui investasi sarana prasarana.

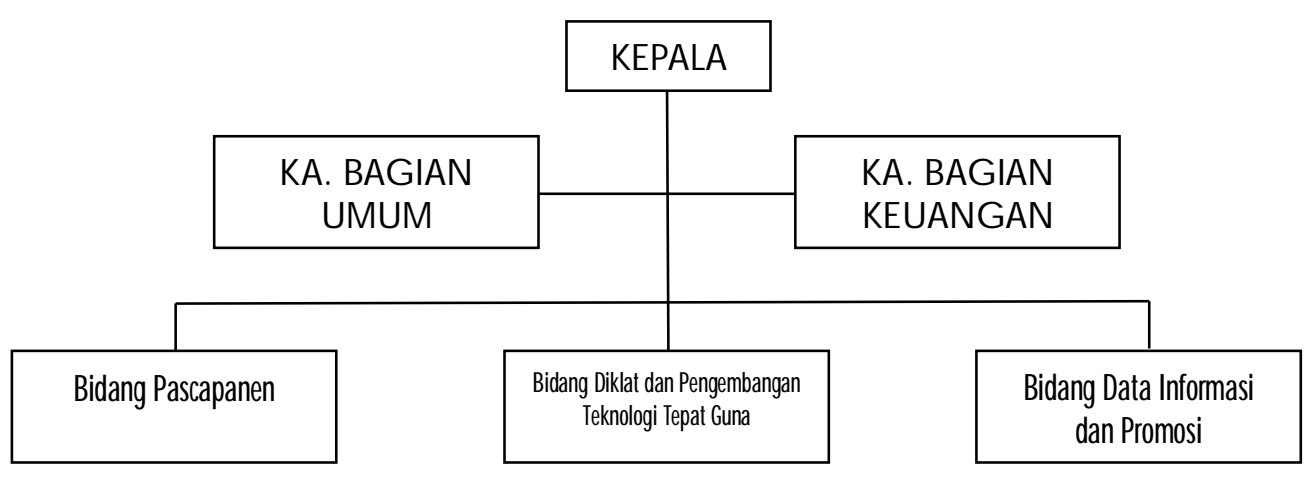




\section{TA田4 MARRKSSROTSATIEM田}

\begin{tabular}{|c|c|c|}
\hline Intand Fatos & 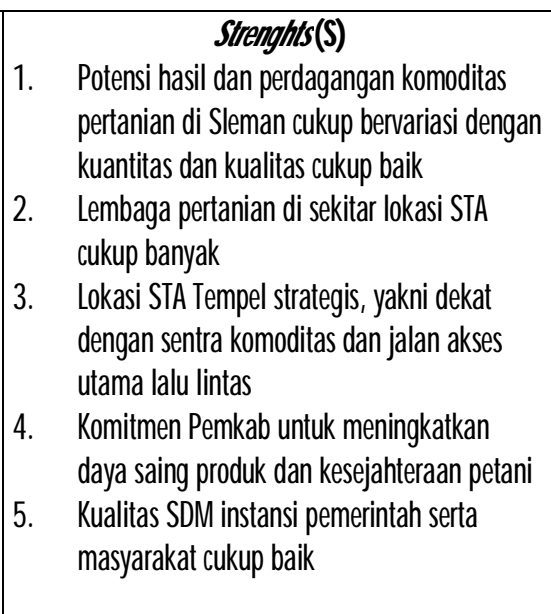 & 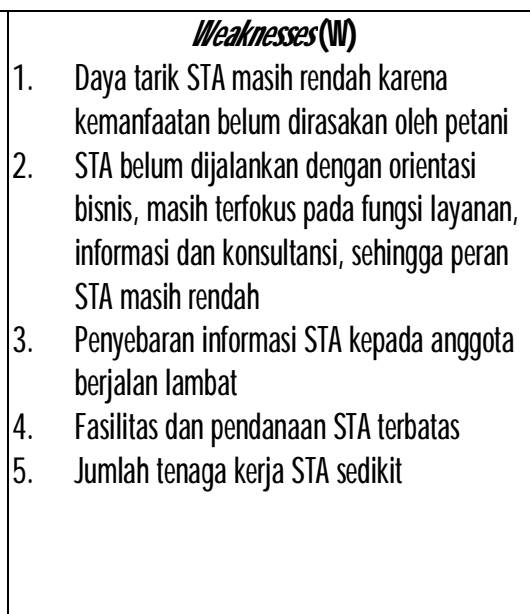 \\
\hline 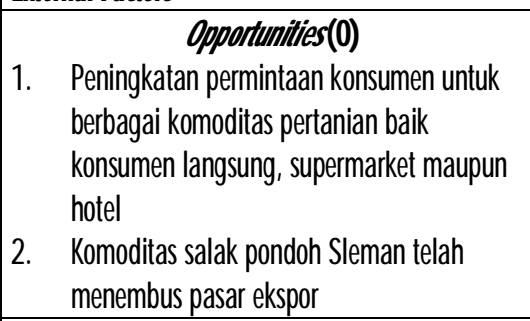 & 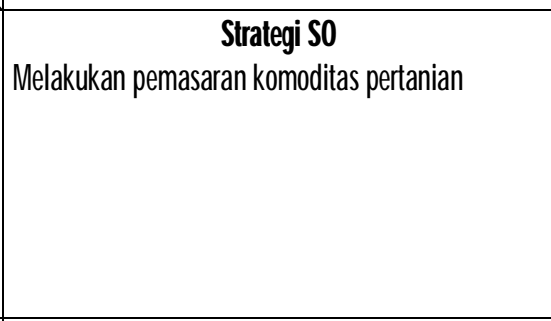 & 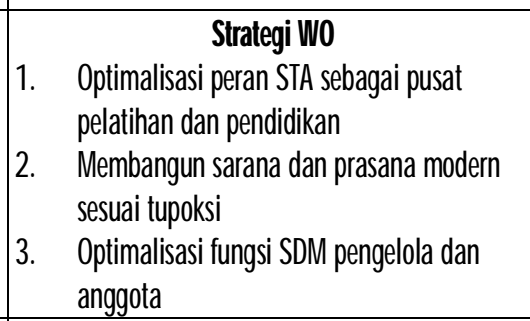 \\
\hline 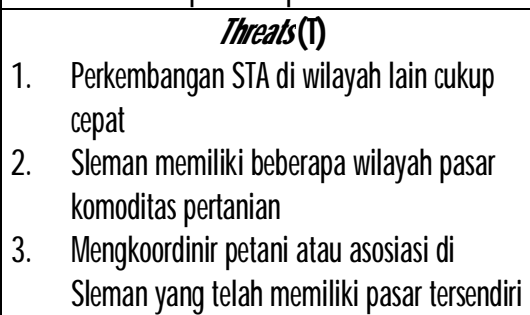 & 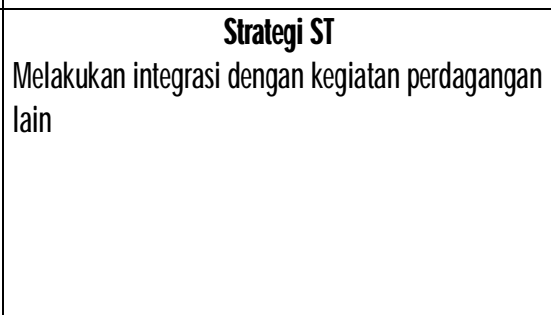 & $\begin{array}{c}\text { Sadaj V } \\
\text { Pengentbangenprosis prolk }\end{array}$ \\
\hline
\end{tabular}

H ambatan dalam akses masuk keSTA merupakan masalah yang perlu diperhatikan. Jalan akses masuk keSTA sangat kecil, sehingga menyulitkan kendaraan pengangkut komoditas masuk keSTA. U ntuk mengatasi hal tersebut sekaligus mengurangi kemacetan, diperlukan pemisahan akses keluarmasuk STA dengan membangun akses jalan yang baru.

Selain sarana prasarana fisik, STA Tempel yang berfungsi sebagai lembaga pemasaran saat ini telah memiliki website, namun website tersebut belum dikelola secara profesional. W ebsiteSTA yang berfungsi sebagai sarana transaksi-jual beli online dan penyebaran informasi seharusnya memuat gambaran tentang komoditas di Sleman. I dealnya websitetersebut memuat informasi tentang harga, jumlah penawaran dan juga jumlah permintaan. Informasi tersebut harus dapat diakses secara mudah oleh pedagang besar, pedagang pengumpul dan petani, disertai dengan pelatihan atau panduan untuk mengaksesnya. A pabila penyebaran informasi melalui internet tidak memungkinkan untuk dikembangkan, maka untuk mendukung fungsi transaksi-jual beli tersebut dapat dilakukan melalui sms. Sarana penyebaran informasi lain adalah dengan membuka peluang penyampaian informasi pertanian di radio.

\section{ANALISIS SWOT DAN STRATEGI PENGEMBANGAN}

$\mathrm{H}$ asil identifikasi kekuatan (strength) dan kelemahan (weakness), dan peluang (opportunities) serta ancaman (threat) STA Tempel yang diperoleh melalui FGD , wawancara, dan pengamatan data sekunder dijabarkan pada Tabel 4. Alternatif strategi yang dirumuskan untuk mengembangkan STA ada enam, yaitu: i) melakukan pemasaran komoditas pertanian, ii) optimalisasi peran STA sebagai pusat pelatihan dan pendidikan, iii) membangun sarana dan prasana modern sesuai tupoksi, iv) optimalisasi fungsi SDM pengelola dan anggota, v) melakukan integrasi dengan kegiatan perdagangan lain, dan vi) mengembangkan kegiatan promosi produk.

1. M elakukan pemasaran komoditas pertanian 
Posisi utama STA adalah sebagai lembaga pemasaran komoditas pertanian, namun fungsi ini belum dijalankan sepenuhnya oleh STA. U ntuk menjadi lembaga pemasaran, STA dapat melakukan transaksi jual beli fisik baik secara langsung maupun tidak langsung. Jual beli fisik secara langsung berupa STA mempertemukan petani dengan konsumen yang dapat dilakukan dengan membuat pasar lelang. Pada dua model pemasaran tersebut, langkah awal yangharus dilakukan adalah identifikasi informasi komoditas potensial pertanian dan SD M, pengumpulan, penyusunan dan sosialisasi sistem jaringan informasi data kelompok tani, kualitas dan kuantitas, harga hasil produk serta ketersediaan produk setiap waktu.

Petani salak pondoh dalam memasarkan hasil produksinya dikoordinir oleh ketua kelompok tani. Data dan sampel produk yang akan ditawarkan kepada pembeli dikelola oleh ketua kelompok tani, untuk selanjutnya diserahkan kepada petugas lelang. Kelompok tani bertugas untuk mengkoordinir jumlah produksi dan melakukan seleksi terhadap produk sesuai dengan kriteria kualitas produk. Kegiatan ini dapat memberikan motivasi bagi petani untuk meningkatkan kualitas produk sekaligus memfungsikan kelompok tani.

Fungsi STA sebagai pasar lelang adalah mempertemukan antara pedagang dengan kelompok tani atau asosiasi. Petani atau asosiasi di Sleman memangtelah memiliki pasar masingmasing, namun dalam kuantitas kecil dan kontinuitas tidak terjaga. Peran STA di sini sangat dibutuhkan, yakni membuat kemitraan dengan pedagang atau perusahaan besar. STA harus memiliki informasi data harga pasar serta perkiraan produksi, sehingga para pembeli mendapatkan informasi yang jelas. STA harus mampu mengatur sepenuhnya proses transaksi antara petani yang diwakili kelompok tani dengan beberapa pedagang, melalui ketentuan yangsudah disepakati sebelumnya. Transaksi dilakukan di STA, namun penyerahan barang dilakukan kelompok tani atau asosiasi di masingmasinglokasi sentra produksi. STA memiliki peluanguntuk men dapatkan pemasukan dengan menerapkan sistem komisi dari besaran komoditas yang terjual melalui STA. Selain itu, STA juga menjadi lembaga penghubung antara petani dengan lembaga keuangan yakni memberikan rekomendasi modal yang dibutuhkan sesuai dengan jumlah produksi yang dapat dijual di tingkat pasar induk.

STA harus dapat mengatur sepenuhnya proses lelang dan transaksi antara petani yang diwakili oleh kelompok tani dengan pedagang melalui ketentuan yang disepakati, misalnya tentang kriteria kualitas produk. STA harus dapat mendistribusikan kebutuhan produk dari pedagang, sehingga secara tidak langsung peran STA adalah sebagai stabilitator kontinuitas produk dan ketersediaan produk di tingkat pasar serta konsumen yang berakhir pada pembentukan harga yang relatif stabil.

Kebutuhan operasional pasar lelang dicukupi dari bagian yang diterima oleh pasar lelang melalui kesepakatan. Bagian yang dapat diterima berasal dari transaksi, pendaftaran pelelangan, sewa ongkos angkut, dan regitrasi internal para pemilik barang dengan pasar lelang sesuai besaran yang disepakati bersama.

A ktivitas tidak langsung berupa transaksi secara online, yakni dengan melalui website atau situs STA. Website merupakan salah satu kebutuhan untuk meningkatkan fungsi STA baik sebagai lembagalayanan, konsultasi maupun sebagai lembaga pemasaran. Website yang ada saat ini dikelola di bawah D inas Pertanian Kabupaten Sleman, sehingga tidak mencerminkan STA secara menyeluruh. Selain itu, website saat ini memiliki tampilan yang relatif sederhana dan kurang menarik. Rencana yang dapat diterapkan oleh STA adalah dengan membuat website secara mandiri melalui tenaga ahli profesional atau penyedia layanan pengelola website yang menampilkan gambaran STA secara mendetail sesuai tupoksi.

U ntuk mempersiapkan website yang optimal, diperlukan database lengkap tentang komoditas pertanian dan potensi pasar, serta optimalisasi SD M untuk mengelola website. STA dapat menyediakan databasepasar dengan rutin melakukan riset pasar. $\mathrm{H}$ al ini sangat diperlukan oleh para pelaku agribisnis seperti dalam penelitian Fauzi, Baga, \& Tinaprilla (2016) tentang pengembangan agribisnis kentang merah di Kabupaten Solok. Salah satu strategi untuk mengetahui peluang dan meminimalkan kelemahan serta respon masyarakat terhadap pengembangan agribisnis kentang merah, maka pelaku dapat memasarkan produknya secara lebih luas melalui riset pasar.

\section{Melakukan integrasi dengan kegiatan perdagangan lain}

Kelompok tani dan asosiasi komoditas serta perusahaan pertanian lain memiliki aktivitas di bidang pertanian yang cukup lama. Kelompok tani sebagai penyuplai komoditas hasil pertanian serta olahannya selama ini memasarkan produk secara mandiri maupun melalui pedagang perantara, sedangkan asosiasi dan perusahaan pertanian merupakan lembaga pemasaran hasil pertanian. Kondisi tersebut merupakan peluang bagi STA untuk menjadikan para pelaku pertanian ini sebagai mitra. STA dapat menjadi mitra bagi petani dengan berperan sebagai lembaga pemasaran, STA juga dapat menjadi mitra asoiasi dan perusahaan pertanian dengan berperan sebagai penyuplai komoditas pertanian. Langkah lain yang dapat dilakukan adalah dengan 
menyediakan kantor pemasaran bersama bagi asosiasi, sehingga mampu memasarkan produk pertanian baik dalam bentuk segar maupun olahan.

\section{Pengembangan promosi produk}

Potensi pertanian yang cukup besar tidak akan diketahui oleh masyarakat umum apabila tidak ada pengenalan dalam bentuk promosi produk. Selama ini promosi produk telah dilakukan dengan melaksanakan gelar produk di beberapa acara. Promosi membuat konsumen mengetahui produk pertanian yang ada di Sleman. Kegiatan ini perlu dilakukan secara terus-menerus untuk memperkenalkan produk dan mencari konsumen baru bagi pemasaran komoditas pertanian di Sleman. Daya jangkau promosi juga dilakukan dengan memanfaatkan sarana komunikasi seperti TV dan radio. Kegiatan promosi selanjutnya yang dibutuhkan adalah branding produk, sehingga produk pertanian di Sleman memiliki ciri khas dan memiliki daya saing dibandingkan komoditas pertanian di wilayah lain.

\section{O ptimalisasi fungsi SD M pengelola dan anggota}

STA perlu meningkatkan kualitas pegawai dalam menjalankan fungsi yang ada. Dalam menjalankan fungsi transaksi jual beli, STA membutuhkan tenaga ahli dalam manajemen pengolalaan kerjasama dengan lembaga pertanian, tenaga ahli untuk mengelola pasar lelang dan pengelolaan outlet serta pasar. Terkait dengan fungsi informasi, maka dibutuhkan tenaga ahli dalam pengel olaan informasi pasar serta pengelolaan website. U ntuk menjalankan fungsi pelatihan dan pendidikan, STA membutuhkan tenaga ahli dalam pengelolaan usaha pertanian mulai dari kegiatan budidaya, pascapanen serta pemasaran. STA Tempel perlu membekali para stafnya agar memiliki kemampuan untuk memberikan pelatihan-pelatihan baik pelatihan yang bersifat budidaya pertanian, maupun pascapanen seperti sortasi, grading, hingga pemasaran. Kegiatan studi banding keSTA lain juga perlu dilakukan untuk melihat manajemen STA di wilayah lain.

Kegiatan STA hingga saat ini belum melibatkan petani secara maksimal, sehingga rasa kepemilikan (sense of belonging) dan kebutuhan petani terhadap STA masih kecil. Keterlibatan petani menjadi sangat penting dalam pengembangan kelembagaan seperti kasus kelembagaan pasar lelang cabai merah di Kecamatan Panjatan. Lembaga tersebut tergolong efektif, hal tersebut ditunjukkan oleh $88,33 \%$ petani menilai lembaga pasar lelang memiliki keefektifan tinggi. Faktor-faktor yang berpengaruh secara nyata terhadap keefektifan lembaga pasar lelang cabai merah diantaranya adalah sikap petani anggota terhadap lembaga pasar lelang dan juga peran ketua kelompok. Semakin positif sikap petani dan semakin tinggi peran ketua kelompok, maka lembaga pasar lelang semakin efektif (D evi, Subejo, \& H arsoyo, 2015).

D alam menjalankan fungsinya sebagai tempat pendidikan dan pelatihan, STA mendorong kelompok tani ataupun pelaku usaha pertanian lain sebagai objek. Kelompok tani ataupun pelaku usaha pertanian lain sangat membutuhkan pendidikan dan pelatihan dalam berbagai subsistem usaha pertanian mengingat persaingan perdagangan komoditas pertanian semakin ketat.

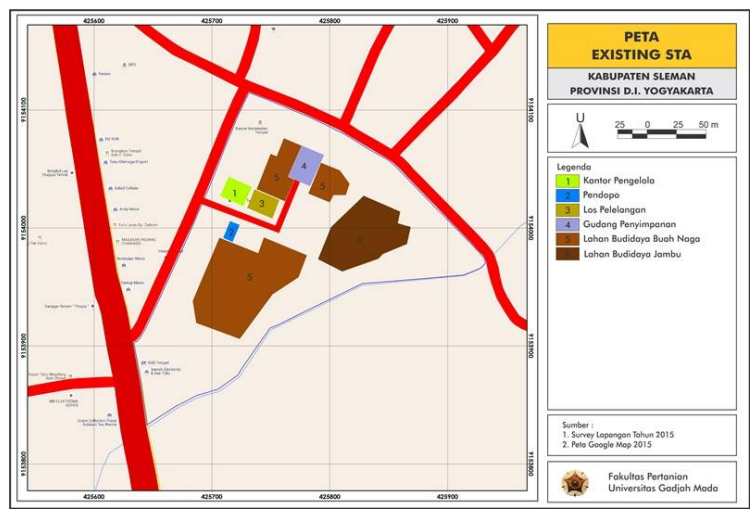

(a)

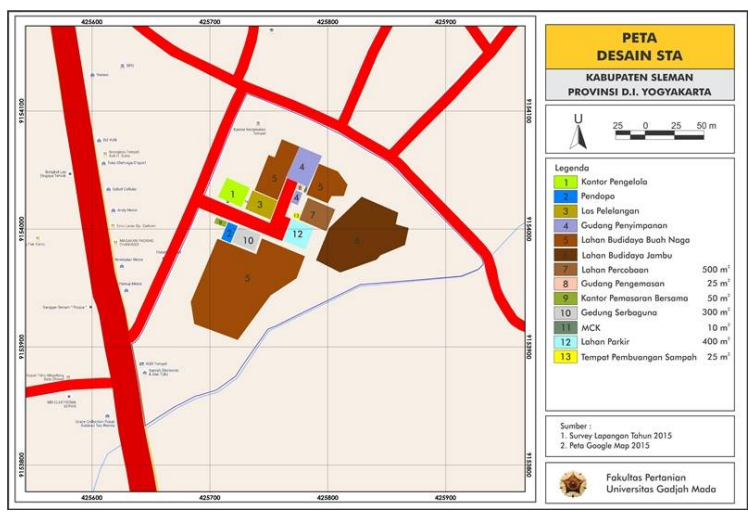

(b)

GAMBAR2 DESANEXSTINGSA(A) DANPENGMANCANSATIEM田(B)

5. Membangun sarana dan prasana modern sesuai tupoksi

Sarana prasarana STA saat ini masih belum ideal, diperlukan berbagai penambahan dan perbaikan. Untuk menjalankan fungsi transaksi jual beli maka bangunan utama yang harus dimiliki STA dalam waktu dekat adalah gudang penyimpanan dan grading. Bangunan tersebut merupakan kebutuhan utama dari asosiasi dan kelompok tani dalam rangka menjual produk. Untuk menyiapkan bangunan gedung penyimpanan dan grading maka yang perlu dilakukan Pemkab Sleman dalam waktu dekat adalah Izin M endirikan Bangunan untuk kedua gedung tersebut. 
Sarana pengairan juga sangat diperlukan baik untuk membersihkan komoditas maupun pengairan kebun. D alam rangka mencuci produk, dapat disiapkan instalasi air yang bersih dan kontinu sepanjang waktu, misal dengan sumur, sedangkan untuk pengairan kebun dilakukan dengan pembuatan embung.

D alam rangka mengimplementasikan STA sebagai pusat pendidikan dan pelatihan, STA harus didukung oleh prasarana dan sarana yang dapat meningkatkan kuantitas dan kualitas pelatihan dan pendidikan. Oleh karena itu, penjelasan mengenai prasarana dan sarana harus ditelaah secara mendalam.

\section{a) Ruang lingkup sarana STA sebagai pusat pendidikan dan pelatihan}

M encakup peralatan yang diperlukan sebagai kelengkapan tiap gedung dalam menjalankan fungsinya untuk meningkatkan kualitas dan relevansi hasil produk dan layanan yang dibagi dalam dua kelompok:

1) Sarana pembelajaran yang terdiri dari proses pelatihan dan pendidikan di ruang kelas berupa papan tulis, LCD projetor, microphone, alat peraga; sarana praktek di lapangan terdiri dari lahan percobaan, alat-alat yang mendukung percobaan budidaya pertanian seperti cangkul, alat semprot, dan instalasi pengairan; ruang simulasi misal ruang untuk simulasi sortasi, simulasi pengemasan, dan simulasi pemasaran.

2) Sarana sumber pelatihan dan pendidikan yang terdiri dari buku teks, jurnal, majalah, lembar informasi, leaflet, dan internet.

\section{b) Kebutuhan prasarana pelatihan}

1) Prasarana bangunan meliputi lahan dan bangunan gedung yang meliputi ruang kantor pengelola, ruang tenaga pengajar, ruang simulasi, ruang perpustakaan, fasilitas kesehatan, fasilitas kebun percobaan dan prasarana olahraga.

2) Prasarana umum meliputi air, sanitasi, drainase, listrik, jaringan telekomunikasi, jaringan internet, parkir, dan taman.

\section{c) Gambaran umum rencana fasilitasi STA sebagai pusat pendidikan dan pelatihan}

1) Asrama gedung dengan kapasitas 100 kamar, masingmasing kamar mampu menampung 2 orang peserta, sehingga total kapasitas asrama sebanyak 200 orang.

2) Ruangkelas sebanyak 4 ruang dengan kapasitas 50 orang per ruang yang dilengkapi dengan LCD projector, papan tulis dan microphone.

3) Ruang kantor pengelola STA

4) Ruang transit pengajar

5) LCD Projector sebanyak 6 buah

6) Layar/screen sebanyak 6 buah

7) Ruangperpustakaan

8) Masjid/ mushola berkapasitas 300 orang

9) Free hotspot area

10) Ruang simulasi, sortasi, pengemasan, pemasaran, lelang dan laintain

11) Lahan percobaan

12)Fasilitas olahraga (lapangan sepak bola dan tenis)

Selain sebagai pelaksana pelatihan dan pendidikan khususnya untuk petani dan umumnya untuk masyarakat, STA juga memiliki potensi besar untuk menambah pendapatan apabila memiliki fasilitas prasarana dan sarana pelatihan yang memadai. STA dapat menyewakan fasilitas yang dimilikinya untuk digunakan sebagai lokasi pelatihan walaupun tidak berkaitan dengan pertanian.

\section{Optimalisasi peran STA sebagai pusat pelatihan dan pendidikan}

a) Pelatihan peningkatan sdm

Salah satu tujan dari pelatihan dan pendidikan adalah untuk meningkatkan kemampuan pegawai agar sesuai dengan perkembangan teknologi. Pengembangan STA juga harus didasarkan pada perubahan teknologi yang terjadi di masyarakat saat ini, agar STA dapat berkembang terus mengikuti perubahan yang terjadi di masyarakat.

b) Pelatihan analisis usahatani

STA sebagai salah satu lembaga yang bertugas memberikan pelatihan bagi petani memiliki tugas untuk memberikan pengetahuan mengenai analisis usahatani kepada para petani. M ateri yang dapat diberikan pada pelatihan analisis usahatani adalah sebagai berikut: 


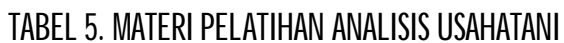

\begin{tabular}{|c|c|c|c|}
\hline $\mathbf{N}$ & Mtai & Mtak & Penticac \\
\hline 1 & $\begin{array}{l}\text { ArdisisPentiayean } \\
\text { clnKertungan } \\
\text { Usdatai }\end{array}$ & $\begin{array}{l}\text { Ceranth dski, } \\
\text { patkek }\end{array}$ & $\begin{array}{l}\text { PetugesSTA Dress } \\
\text { Petarian Penyeluh } \\
\text { Petarian }\end{array}$ \\
\hline 2 & $\begin{array}{l}\text { ArdsisKeaydan } \\
\text { (Break Even Point, Cash } \\
\text { Retum on Assets Ratio, } \\
\text { Benefit Cost Ratio) }\end{array}$ & $\begin{array}{l}\text { Ceranah dskis, } \\
\text { pdktk }\end{array}$ & $\begin{array}{l}\text { PetugesSTA Dress } \\
\text { Petarian Penyelh } \\
\text { Petarian }\end{array}$ \\
\hline
\end{tabular}

c) Pelatihan sortasi, pengemasan, dan pengolahan hasil pertanian Pascapanen hasil pertanian adalah semua kegiatan yang dilakukan sejak proses pemanenan hasil pertanian, sampai dengan proses yang menghasilkan produk setengah jadi. Kegiatan pascapanen meliputi panen, pengumpulan, perontokan/ pemipilan, pengupasan, pencucian, sortasi, grading, pengangkutan, pengeringan, penggilingan, penepungan, pengemasan, dan penyimpanan.

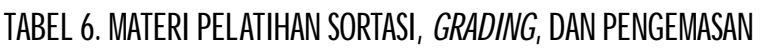

\begin{tabular}{|c|c|c|c|}
\hline $\mathbf{N}$ & Nai & Noteptetifr & Penlicac \\
\hline 1 & $\begin{array}{l}\text { Metodesatai yeng } \\
\text { testandaisad }\end{array}$ & Gand', dski & Deperincigkox \\
\hline 2 & $\begin{array}{l}\text { Pergerdantendodog } \\
\text { sotad yengtdah } \\
\text { dapdikaikan }\end{array}$ & $\begin{array}{l}\text { Kurjunger, } \\
\text { paktek }\end{array}$ & 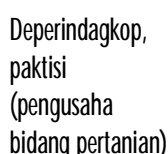 \\
\hline 3 & 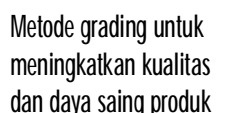 & Geratah dski & Depeindedkop \\
\hline 4 & $\begin{array}{l}\text { Tekndogj pereapen } \\
\text { gadng(temæak } \\
\text { posesperetumkenkas } \\
\text { kdaspoulk) }\end{array}$ & $\begin{array}{l}\text { Kurjunger, } \\
\text { paktek }\end{array}$ & $\begin{array}{l}\text { Depeinckgkop } \\
\text { pattis }\end{array}$ \\
\hline 5 & 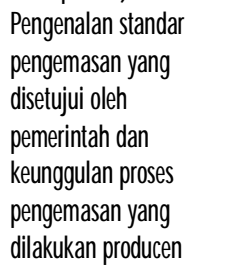 & Ceratah dski & $\begin{array}{l}\text { Depeindadkpp } \\
\text { BPOM Ali d } \\
\text { bickng } \\
\text { pergddantail } \\
\text { petarian }\end{array}$ \\
\hline 6 & $\begin{array}{l}\text { Pererpentedridog } \\
\text { pergermanyengtdah } \\
\text { dlikkan }\end{array}$ & $\begin{array}{l}\text { Kujungen } \\
\text { paktak }\end{array}$ & Pddis \\
\hline
\end{tabular}

d) Pelatihan pengolahan pascapanen dan pemasaran produk pertanian

Untuk meningkatkan kualitas sumber daya petani dan pedagang, perlu diadakan program pelatihan yang berkaitan dengan pascapanen dan pemasaran. $\mathrm{Hal}$ ini bertujuan untuk memberikan pemahaman dan pengetahuan baik secara teori maupun teknis di lapangan tentang cara pengelolaan pascapanen untuk menekan penyusutan hasil, mempertahankan kualitas produk, memperpanjang masa simpan, dan meningkatkan daya saing produk pertanian. Selain itu, pelatihan tersebut juga bertujuan untuk mendorong pelaku usaha untuk menerapkan sistem dan teknologi pengolahan pascapanen dan pemasaran hasil serta untuk mengurangi risiko penurunan kualitas produk pascapanen.

\section{TA由田7. MA由R田AIIHANPASCAPANENDANPEMASABAN}

\begin{tabular}{|c|c|c|}
\hline $\mathbf{N}$ & Mtai & Neranted Penticac \\
\hline 1 & $\begin{array}{l}\text { Perarganenpodks } \\
\text { pargan/standerparganstht }\end{array}$ & 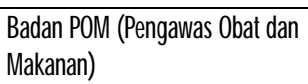 \\
\hline 2 & 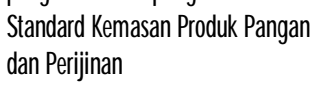 & Cispeincbagk \\
\hline$\Xi$ & Setifikei H杖 & Mu \\
\hline 4 & $\begin{array}{l}\text { Tekndog Penyimparen Hail } \\
\text { Petarian }\end{array}$ & 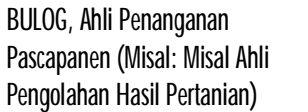 \\
\hline 5 & AndisisPeduengPaser & Dsperinckgkpp \\
\hline$\epsilon$ & PeluesanPenasen Petaria & 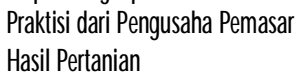 \\
\hline 7 & $\begin{array}{l}\text { Perarganen pescapene, Ardsis } \\
\text { ratai rilai, Penjimparenpodk } \\
\text { petariandankenitran }\end{array}$ & 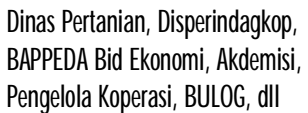 \\
\hline
\end{tabular}

\section{KESIMPULAN}

STA Tempel belum mampu melaksanakan fungsinya secara optimal dan manfaatnya juga belum dirasakan oleh petani karena infrastruktur, sarana promosi, tenaga kerja dan pendanaan yang terbatas. Di sisi lain, petani telah memiliki pasar komoditas tersendiri. Penguatan kinerja STA Tempel dilakukan dengan beberapa perbaikan antara lain: peningkatan fungsi pemasaran komoditas pertanian, melakukan integrasi dengan kegiatan perdagangan lain, pengembangan promosi produk, optimalisasi fungsi SDM pengelola dan anggota, membangun sarana dan prasana modern sesuai tupoksi serta optimalisasi peran STA sebagai pusat pelatihan dan pendidikan

\section{UCAPAN TERIMA KASIH}

Penulis mengucapkan terima kasih kepada Badan Perencanaan Pembangunan D aerah K abupaten Sleman yang telah memberi dukungan finansial terhadap pelaksanaan penelitian "Kajian Strategis Pengembangan Sub Terminal A gribisnis K abupaten Sleman". 


\section{DAFTAR PUSTAKA}

Anindita, R. (2008). Analisis Kinerja Sub Terminal Agrobisnis Mantung: Studi Kasus pada Pemasaran Sayuran Kubis di Desa Ngabab, Kecamatan Pujon, Kabupaten Malang. Majalah Ekonomi, 18(3): 244256.

Bank Indonesia. (2015). Skema Pembiayaan Pertanian dengan Pendekatan Konsep Rantai Nilai. BI, Jakarta.

Badan Perencanaan Pembangunan Daerah Sleman. (2006). Studi Kelayakan (Feasibility Study) STA Tempel. Bappeda Sleman, Sleman.

Cahyono, W., Kusnandar, \& Sri, M. (2013). Analisis Efisiensi Pemasaran Sayuran Wortel di Sub Terminal Agribisnis Kabupaten Karanganyar. Agribusiness Review, 1(1): 1-20.

Devi, P., Subejo, \& Harsoyo. (2015). Keefektifan Lembaga Pasar Lelang Cabai Merah di Kecamatan Panjatan Kabupaten Kulon Progo. Agro Ekonomi, 26(2): 139-149.

Fatih, C. (2010). Strategi Pengembangan Agroindustri Perikanan Laut di Kabupaten Tuban. J-SEP, 4(3): 77-88.

Fauzi, D., Baga, L. M., \& Tinaprilla, N. (2016). Strategi Pengembangan Agribisnis Kentang Merah di Kabupaten Solok. AGRARIS: Journal of Agribusiness and Rural Development Research, 2(1): 87-96.

Noni, S., Darmawan, D. P., \& Suarthana, W. (2013). Prospek Pembangunan Sub Terminal Agribisnis dalam Rangka Perbaikan Kinerja Pemasaran dan Peningkatan Pendapatan Petani di W ilayah Timur Kabupaten Sikka. Jurnal Manajemen Agribisnis, 3(1): 53-59.

Pujihanto. (2010). Kajian Kelembagaan Pembangunan Pertanian Kasus Sub Terminal Agribisnis di Indonesia. Agritech, 12(2): 137-157.

Suranto. (2010). Manajemen dan Tingkat Kepuasan Pedagang Pengguna pada Sub Terminal Agribisnis Sewukan di Kabupaten Magelang. Universitas Diponegoro.

Susanawati, Jamhari, Masyhuri, \& Darwanto, D. H. (2015). Integrasi Pasar Bawang Merah di Kabupaten Nganjuk. AGRARIS: Journal of Agribusiness and Rural Development Research, 1(1): 43-51. 